\title{
ANALISIS PERBANDINGAN KENAIKAN BERAT BADAN IBU YANG MENGGUNAKAN KB SUNTIK CYCLOFEM DAN DEPO MEDROKSI PROGESTERON ASETAT (DMPA) DI PUSKESMAS PASAR TERUSAN KABUPATEN BATANGHARI JAMBI
}

\author{
Festy Ladyani ${ }^{1}$ \\ ${ }^{1}$ Prodi Pendidikan Dokter, Fakultas Kedokteran, Universitas Malahayati
}

\begin{abstract}
ABSTRAK
Latar Belakang: Kontrasepsi suntik terbagi menjadi dua yaitu KB suntik Cyclofem mengandung hormon estrogen dan progesteron yang diberikan setiap bulan dan KB suntik Depo Medroksi Progesteron Asetat (DMPA) mengandung hormon progesteron yang diberikan setiap 3 bulan. Kontrasepsi suntik memiliki kelebihan dan kekurangan. Kelebihan dari kontrasepsi suntik diantaranya efektif, tidak mengganggu hubungan suami istri, tidak perlu menyimpan obat suntik. Kekurangan dari kontrasepsi suntik adalah adanya peningkatan berat badan 1-5 kg. Tujuan penelitian: Untuk mengetahui perbandingan kenaikan berat badan ibu yang menggunakan KB Suntik Cyclofem dan Depo Medroksi Progesteron Asetat (DMPA) di Puskesmas Pasar Terusan Kabupaten Batanghari Jambi.Metode Penelitian: Penelitian Survei Analitik, mengunakan analisa observasional dengan pendekatan cross sectional. Sampel penelitian ini adalah akseptor KB suntik Cyclofem dan Depo Medroksi Progesteron Asetat (DMPA) dengan masa penggunaan KB selama 1-2 tahun di Wilayah Kerja Puskesmas Pasar Terusan Kabupaten Batanghari Jambi sebanyak 242 orang pada waktu dilakukan penelitian yang memenuhi kriteria penelitian. Analisis bivariat pada penelitian ini menggunakan t-test independent. Hasil Penelitian: Ada perbedaan kenaikan berat badan ibu yang menggunakan KB Suntik Cyclofem dan Depo Medroksi Progesteron Asetat (DMPA) di Puskesmas Pasar Terusan Kabupaten Batanghari Jambi dengan $p$ value $=0,001$. Simpulan: Ada perbedaan kenaikan berat badan ibu yang menggunakan KB Suntik Cyclofem dan Depo Medroksi Progesteron Asetat (DMPA) di Puskesmas Pasar Terusan Kabupaten Batanghari Jambi.
\end{abstract}

\section{LATAR BELAKANG}

Kontrasepsi adalah upaya mencegah kehamilan yang bersifat sementara ataupun menetap. Saat ini tersedia banyak metode alat kontrasepsi meliputi: Suntik, pil, implant, IUD, kondom. Salah satu kontrasepsi yang populer dan banyak dipakai di Indonesia adalah kontrasepsi suntik (BKKBN, 2009). Kontrasepsi suntik terbagi menjadi dua yaitu KB suntik Cyclofem mengandung hormon estrogen dan progesteron yang diberikan setiap bulan dan KB suntik Depo Medroksi Progesteron Asetat (DMPA) mengandung hormon progesteron yang diberikan setiap 3 bulan. Kontrasepsi suntik memiliki kelebihan dan kekurangan. Kelebihan dari kontrasepsi suntik diantaranya efektif, tidak mengganggu hubungan suami istri, tidak perlu menyimpan obat suntik. Kekurangan dari kontrasepsi suntik adalah adanya peningkatan berat badan 1-5 kg. Peningkatan berat badan adalah hal yang paling sering dikeluhkan oleh akseptor $\mathrm{KB}$ suntik (Saifuddin, Affandi, B, Baharuddin, M,
Soekaemi, S, 2006). Pada tahun 2012 jumlah akseptor KB di Indonesia yaitu jumlah akseptor KB Suntik sebanyak $(65,31 \%)$ dibandingkan dengan KB lainnya $(16,14 \%)$. Sedangkan untuk Provinsi Jambi pada tahun 2012 jumlah akseptor KB Suntik sebanyak $(37,90 \%)$ dibandingkan dengan KB lainnya (14,39\%) (Depkes RI, 2012). Berdasarkan data dari BKKBN tahun 2012 di Kabupaten Batanghari jumlah akseptor KB Suntik $(45,63 \%)$ dibandingkan dengan KB lainnya $(34,34 \%){ }^{4}$ Berdasarkan data rekapitulasi pendataan Puskesmas tahun 2012 di Kecamatan Pasar Terusan Kabupaten Batanghari, akseptor KB Suntik sebanyak 734 orang dengan jumlah akseptor yang termasuk dalam kriteria inklusi penggunaan $K B$ suntik selama 1-2 tahun sebanyak 242 orang. Perincian pengguna kontrasepsi Cyclofem sebanyak 75 orang sedangkan yang menggunakan kontrasepsi DMPA sebanyak 167 orang dibandingkan dengan KB lainnya 197 orang. Peningkatan berat badan terjadi karena pengaruh hormon estrogen yang dapat menyebabkan retensi 
cairan dan garam yang dapat memicu peningkatan berat badan dan hormon progesteron merangsang pusat pengendalian nafsu makan di hipothalamus yang dapat meningkatkan nafsu makan sehingga dapat terjadi peningkatan berat badan. ${ }^{6}$ Peningkatan berat badan merupakan salah satu efek dari menggunakan kontrasepsi hormonal, hal ini dapat menjadi keluhan yang mengganggu pada wanita, sekalipun berat badan ini bukan merupakan fenomena yang seragam (Manuaba, IB, 2012). Sebagian pertambahan berat badan dapat disebabkan oleh retensi cairan, tetapi cenderung terjadi akibat peningkatan lemak tubuh sebanyak 3,4\% dalam waktu 3 tahun pemakaian (Hartono, H, 2002). Berdasarkan penelitian yang dilakukan oleh University of Texas Medical Branch (UTMB) tahun 2008, wanita yang menggunakan kontrasepsi hormonal Depo Medroxy Progesterone Acetate (DMPA) atau dikenal dengan kontrasepsi suntik 3 bulan, rata-rata mengalami peningkatan berat badan sebanyak 11 pon atau $5,5 \mathrm{~kg}$ dan mengalami peningkatan lemak tubuh sebanyak 3,4\% dalam waktu 3 tahun pemakaian.

\section{PENELITIAN}

\section{Analisis data}

Analisis bivariat pada penelitian ini menggunakan t-test independent. Data (variabel independen) yang dibandingkan
Jenis Penelitian Penelitian ini merupakan penelitian Survei Analitik. Survei analitik

Rancangan Penelitian Penelitian ini mengunakan analisa observasional dengan pendekatan cross sectional

\section{Populasi}

Dimana populasi yang masuk kedalam kriteria inklusi sebanyak 242 orang, dengan kriteria pengguna KB cyclofem sebanyak 75 orang dan KB DMPA sebanyak 167 orang.

\section{Sampel}

Sampel penelitian ini adalah akseptor KB suntik Cyclofem dan Depo Medroksi Progesteron Asetat (DMPA) dengan masa penggunaan KB selama 1-2 tahun di Wilayah Kerja Puskesmas Pasar Terusan Kabupaten Batanghari Jambi sebanyak 151 Kriteria Insklusi

a. Responden telah menggunakan kontrasepsi hormonal KB suntik 1-2 tahun

b. Responden yang bersedia untuk mengikuti penelitian dan telah menandatangani Informed Consent.

\section{Variabel Penelitian}

Adapun variabel dalam penelitian ini adalah penggunaan kontrasepsi Cyclofem dan Depo Medroksi Progesteron Asetat (DMPA) sebagai variabel independent dan peningkatan berat badan sebagai variabel dependent.

adalah berat badan akseptor KB suntik Cyclofem dan Depo Medroksi Progesteron Aseta (DMPA).

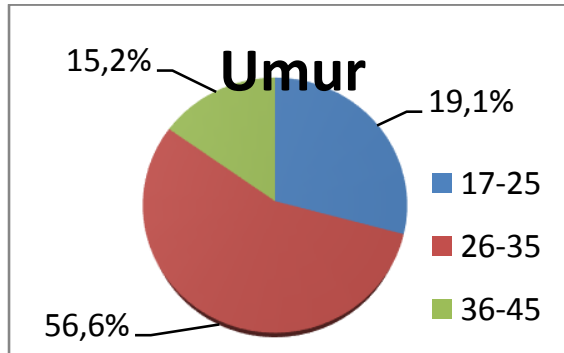

\section{Gambar 1 Karakteristik Subjek Penelitian Berdasarkan Umur di Puskesmas Pasar Terusan Kabupaten Batanghari Jambi}

Berdasarkan gambar 1 didapatkan hasil subyek penelitian paling banyak dengan rentang umur 26-35 tahun, yaitu sebanyak 84 orang $(55,6 \%)$. Sedangkan pada responden dengan rentang umur 17-25 tahun sebanyak 44 orang $(19,1 \%)$ dan rentang umur 36-45 tahun sebanyak 23 orang $(15,2 \%)$.

\section{KB Suntik Cyclofem}

Berdasarkan penelitian yang dilakukan di Puskesmas Pasar Terusan Kabupaten Batanghari Jambi berdasarkan kenaikan berat badan menggunakan KB suntik Cyclofem pada responden dapat dilihat pada gambar diagram pie dibawah ini: 


\section{KB Suntik Cyclofem}

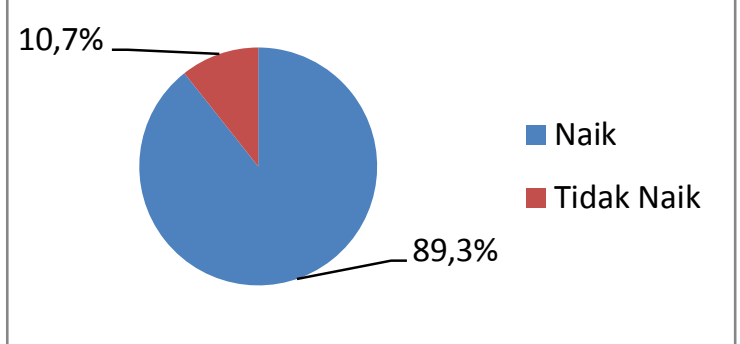

Gambar 2 Distribusi Frekuensi Responden Berdasarkan Kenaikan Berat Badan Ibu Menggunakan KB Suntik Cyclofem di Puskesmas Pasar Terusan Kabupaten Batanghari Jambi.

Berdasaarkan gambar 2 diatas menunjukkan distribusi responden berdasarkan kenaikan berat badan dari 75 responden yang mengalami kenaikan berat badan sebanyak 67 responden $(89,3 \%)$ lebih banyak dibandingkan responden yang tidak mengalami kenaikan berat badan, yaitu sebanyak 8 responden $(10,7 \%)$.

\section{KB Suntik DMPA}

Berdasarkan penelitian yang dilakukan di Puskesmas Pasar Terusan Kabupaten Batanghari Jambi berdasrakan kenaikan berat badan menggunakan KB suntik DMPA pada responden dapat dilihat pada gambar diagram pie dibawah ini

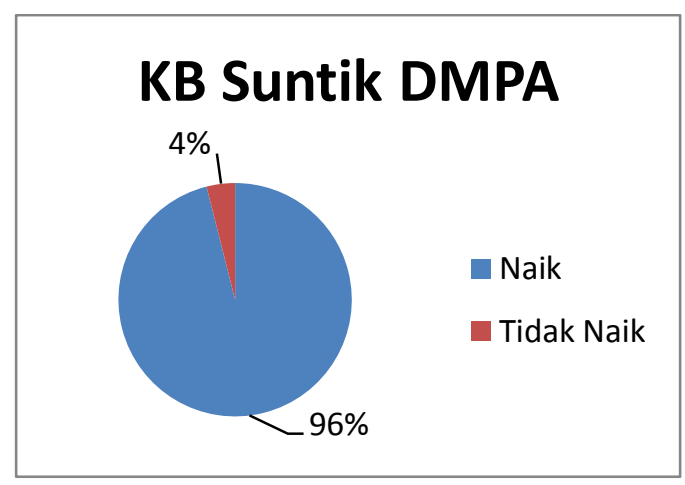

Gambar 3 Distribusi Ferekuensi Responden Berdasarkan Kenaikan Berat Badan Ibu Menggunakan KB Suntik DMPA di Puskesmas Pasar Terusan Kabupaten Batanghari Jambi

Berdasarkan gambar 3 diatas menunjukkan distribusi responden berdasarkan kenaikan berat badan dari 76 responden yang menggunakan KB Suntik DMPA, didapatkan responden yang mengalami kenaikan berat badan sebanyak 73 responden (96\%) lebih banyak dibandingkan responden yang tidak mengalami kenaikan berat badan, yaitu sebanyak 3 responden (4\%).

\section{Hasil Analisa Bivariat}

Sebelum dilakukan uji bivariat dilakukan uji normalitas data. Dari uji KolmogorovSmirnov distribusi data dalam batas normal. Data dianalisa dengan uji statistik $t$-test independent didapatkan hasil sebagai berikut:

Tabel 1 Perbandingan Kenaikan Berat Badan Ibu Yang Menggunakan KB Suntik Cyclofem dan Depo Medroksi Progesteron Asetat (DMPA) di Puskesmas Pasar Terusan Kabupaten Batanghari Jambi

\begin{tabular}{lccccc}
\hline $\begin{array}{c}\text { Kenaikan } \\
\text { berat badan }\end{array}$ & $\mathbf{N}$ & Mean & Std. Dev & $\mathbf{9 5 \%} \mathbf{C I}$ & p-value \\
\hline DMPA & 76 & 7,96 & 2,92 & $1,94-10,73$ & \multirow{2}{*}{0,001} \\
\hline Cyclofem & 75 & 3,89 & 2,29 & $0,48-4,73$ & \\
\hline
\end{tabular}


Berdasarkan tabel 1 diketahui bahwa ratarata kenaikan berat badan ibu yang menggunakan KB suntik Cyclofem adalah 3,89 dengan standar deviasi 2,29 dan 95\% $\mathrm{CI}=0,48-4,73$. Sedangkan rata-rata kenaikan berat badan pada ibu yang menggunakan KB suntik DMPA adalah 7,96, dengan standar deviasi 2,92 dan $95 \% \mathrm{CI}=$ $1,94-10,73$. Hasil uji statistik dengan uji $t$ independent didapatkan $p$-value $=0,001(p$ value $<\mathrm{a}=0,05$ ), yang berarti ada perbedaan kenaikan berat badan ibu yang menggunakan KB suntik Cyclofem dan Depo Medroksi Progesteron Asetat (DMPA) di Puskesmas Pasar Terusan Kabupaten Batanghari Jambi.

\section{PEMBAHASAN}

\section{Karakteristik Subjek Penelitian Berdasarkan Sebaran Umur}

Hasil penelitian menunjukkan akseptor dengan rentang umur 17-25 tahun sebanyak 44 orang $(19,1 \%), 26-35$ tahun, yaitu sebanyak 84 orang $(55,6 \%)$, dan usia $36-45$ tahun sebanyak 23 orang $(15,2 \%)$. Berdasarkan hasil tersebut dapat penulis simpulkan bahwa rentang umur 26-35 tahun yang paling banyak dalam penelitian ini. Menurut Hartanto pada masa umur ini diperlukan jenis kontrasepsi yang mempunyai efektivitas cukup tinggi, reversibilitas cukup tinggi karena peserta masih mengharapkan punya anak lagi, dapat dipakai dua sampai empat tahun yaitu sesuai dengan jarak kehamilan anak yang direncanakan (Hartanto, H, 2004).

Pemilihan KB suntik adalah pilihan rasional dibandingkan dengan KB lainnya selain cocok untuk usia ini, KB suntik cukup ekonomis sehingga dapat terjangkau di semua lapisan masyarakat. Hal inilah yang menjadi alasan mengapa pada usia lebih dari 30 tahun lebih memilih KB suntik dibandingkan dengan jenis KB lainnya. KB suntik mungkin kesuburan mungkin baru kembali satu tahun setelah suntikan dihentikan, tetapi KB suntik tidak menyebabkan kemandulan permanen. Suntikan KB bisa menyebabkan penambahan berat badan yang sifatnya ringan. (Hartanto, $H, 2004)$.

\section{Perbandingan Kenaikan Berat Badan Ibu yang menggunakan KB Suntik Cyclofem dan KB Suntik DMPA}

Berdasarkan hasil penelitian terdapat perbedaan yang signifikan antara kenaikan berat badan ibu yang menggunakan KB suntik Cyclofem dan KB suntik DMPA dengan hasil penelitian rata-rata kenaikan berat badan ibu yang menggunakan KB suntik Cyclofem adalah 3,89 dengan standar deviasi 2,29. Sedangkan rata-rata berat badan pada ibu yang menggunakan KB suntik DMPA lebih besar dari KB suntik Cyclofem, yaitu 7,96 dengan standar deviasi 2 ,92. Hasil uji statistik dengan uji $t$ independent didapatkan $p$-value $=0,001(p$ value $<\mathrm{a}=0,05$ ), yang berarti ada perbedaan antara kenaikan berat badan ibu yang menggunakan KB suntik Cyclofem dan Depo Medroksi Progesteron Asetat (DMPA) di Puskesmas Pasar Terusan Kabupaten Batanghari Jambi.

Hal ini sesuai dengan teori bahwa DMPA adalah 6-alfa-medroksiprogesteron merupakan long-acting progestin yang digunakan untuk tujuan kontasepsi parenteral, mempunyai efek progesteron yang kuat dan sangat efektif. Dalam penggunaan jangka panjang DMPA dapat memicu peningkatan berat badan, kekeringan vagina, menurunkan libido, gangguam emosi, sakit kepala, jerawat karena penggunaan hormonal dapat menimbulkan ketidak seimbangan antara hormon estrogen dan progesteron dalam tubuh sehingga mengakibatkan terjadi perubahan sel yang normal menjadi tidak normal (Sarwono, P, 2006). Pemakaian kontrasepsi suntik bulanan maupun tribulanan mempunyai efek samping utama yaitu perubahan berat badan. Faktor yang mempengaruhi perubahan berat badan akseptor KB suntik adalah adanya hormon progesteron yang kuat sehingga merangsang nafsu makan yang ada di hipotalamus. Dengan adanya nafsu makan yang lebih banyak dari biasanya tubuh akan kelebihan zat-zat gizi. Kelebihan zat-zat gizi oleh hormon progesteron dirubah menjadi lemak dan disimpan di bawah kulit. Perubahan berat badan ini akibat adanya penumpukan lemak yang berlebihan hasil sintesa dari karbohidrat menjadi lemak (Mansjoer, A, 2003). Menurut Hartanto salah satu efek samping dari metode suntikan adalah adanya penambahan berat badan. Pada umumnya pertambahan berat badan tidak terlalu besar, bervariasi antara kurang dari satu $\mathrm{kg}$ sampai lima $\mathrm{kg}$ dalam tahun pertama penyuntikan. Tampaknya terjadi karena bertambahnya lemak tubuh, dan bukan karena retensi cairan tubuh. Hipotesa para ahli DMPA merangsang pusat pengendalian nafsu makan di hipotalamus 
yang menyebabkan akseptor makan lebih banyak dari biasanya. Hal ini juga memperkuat bahwa kontrasepsi suntik DMPA merupakan faktor yang menyebabkan kenaikan berat badan.

Wanita yang menggunakan kontrasepsi DMPA (Depo medroxy Progesterone Acetate) atau dikenal dengan KB suntik tiga bulan, rata-rata mengalami peningkatan berat badan sebanyak 11 pon atau 5,5 kilogram, dan peningkatan lemak tubuh sebanyak $3,4 \%$ dalam waktu tiga tahun pemakaian, penelitian ini sesuai dengan penelitian yang dilakukan oleh University of Texas Medical Branch (UTBM). Sedangkan pada kontrasepsi suntik bulanan efek samping terhadap berat badan sangatlah ringan, umumnya pertambahan berat badan sedikit (Dinas Kesehatan Provinsi Jambi, 2012). Bukti menunjukkan kenaikan berat badan selama penggunaan DMPA, hal ini karena dalam kontrasepsi suntik mengandung hormon progesteron dan estrogen. Hormon estrogen merangsang pusat nafsu makan yang ada di hipotalamus. Dengan bertambahnya nafsu makan, karbohidrat yang dikonsumsi dari makanan oleh hormon progesteron dirubah menjadi lemak yang menyebabkan berat badan bertambah. Efek samping utama pemakai DMPA adalah kenaikan berat badan. Sebuah penelitian melaporkan peningkatan berat badan lebih dari 2,3 kilogram pada tahun pertama dan selanjutnya meningkat secara bertahap hingga mencapai 7,5 kilogram selama enam tahun. Sedangkan pemakaian Cyclofem berat badan meningkat rata-rata dua hingga tiga kilogram tahun pertama pemakaian, dan terus bertambah selama tahun kedua. (Varney, 2007) KB suntik Cyclofem mengandung hormon estrogen dan progesteron dimana fungsi dari hormon estrogen adalah untuk menekan efek kerja dari hormon progesteron. Hal inilah yang mengakibatkan efek dari KB suntik Cyclofem terhadap peningkatan berat badan tidak terlalu besar antara dua hingga tiga kilogram pada tahun pertama penyuntikan. Sedangkan pada KB suntik DMPA hanya mengandung hormon progesteron saja.

Hasil penelitian ini sesuai jika dikaitkan dengan penelitian tentang pengaruh $\mathrm{KB}$ Suntik DMPA terhadap peningkatan berat badan di BPS Siti Syamsiyah Wonokarto Wonogiri yang didapatkan hasil bahwa, akseptor KB DMPA lebih berisiko mengalami kenaikan berat badan dengan rata-rata 5,310 lebih besar dibandingkan bukan akseptor KB suntik DMPA dengan nilai $p=0,148<0,005.25$ Sedangkan menurut penelitian Soemardini, dkk. Tentang hubungan antara frekuensi pemberian $\mathrm{KB}$ suntik 1 bulan dengan peningkatan berat badan di bidan praktek swasta kecamatan kedemang kota Probolinggo yang didapatkan hasil bahwa, ada korelasi yang signifikan antara frekuensi pemberian KB suntik 1 bulan terhadap kenaikan berat badan dengan nilai $r=0,995 ; p=0,000$. Hasil tersebut semakin memperkuat dugaan adanya keterkaitan pengguna kontrasepsi suntik Cyclofem maupun DMPA terhadap perubahan berat badan.

\section{Keterbatasan Penelitian}

Penelitian ini tidak dicari riwayat berat badan sebelum ibu memakai kontrasepsi tersebut.

\section{SIMPULAN}

Berdasarkan hasil penelitian dan pembahasan, maka dapat diambil kesimpulan sebagai berikut:

1. Rata-rata kenaikan berat badan ibu yang menggunakan KB suntik Cyclofem adalah 3,89 dengan standar deviasi 2,29.

2. Rata-rata kenaikan berat badan ibu yang menggunakan KB suntik DMPA adalah 7,96 dengan standar deviasi 2,92.

3. Ada perbedaan kenaikan berat badan ibu yang menggunakan KB Suntik Cyclofem dan Depo Medroksi Progesteron Asetat (DMPA) di Puskesmas Pasar Terusan Kabupaten Batanghari Jambi dengan $p$ value $=0,001$.

\section{DAFTAR PUSTAKA}

BKKBN, 2009. Keluarga Berencana dan Kontrasepsi. Jakarta;

Saifuddin, Affandi, B, Baharuddin, M, Soekaemi, S, 2006. Buku Panduan Praktis Pelayanan Kontrasepsi. Yayasan Bina Pustaka Sarwono Prawirohardjo. Jakarta;

Depkes RI, 2012. Riset Kesehatan Dasar. Badan Penelitian dan Pengembangan Kesehatan. Jakarta;

Dinas Kesehatan Provinsi Jambi, 2012. Profil Kesehatan Provinsi Jambi. Jambi;

Laporan Rekapitulasi Puskesmas Pasar Terusan kabupaten Batanghari. Jambi; 2013.

Hartanto, H, 2004. Keluarga Berencana dan Kontrasepsi. Pustaka Sinar Harapan. Jakarta; 
Manuaba, IB, 2012. Ilmu Kebidanan, Penyakit Kandungan, dan Keluarga Berencana untuk Pendidikan. EGC. Jakarta;

Hartono, H, 2002. Obstetri Williams. Jakarta. EGC.

UTBM. Kontrasepsi Suntik Menyebabkan Peningkatan Berat Badan; 2008 http://www.klikdokter.com/article/detail/ 704. diakses tanggal 12 november 2013

Mansjoer, A, 2003. Kapita Selekta Kedokteran, Jilid Dua Edisi Tiga. FKUI. Jakarta;
Surono, C, 2004. Peningkatan Berat Badan. Modul Kesehatan. Jakarta;

Varney, 2007. Buku Ajar Asuhan Kebidanan. Edisi Empat. EGC. Jakarta; .

Sarwono, P, 2006. Ilmu Kandungan. Bina Pustaka Sarwono Prawirohardjo. Jakarta;

Soemardini, Lilik, Z, Amaliatus, S, 2012. Hubungan Antara Frekuensi Pemberian KB Suntik 1 Bulan Dengan Peningkatan Berat Badan Di Bidan Praktek Swasta Kecamatan Kedemang Kota Probolinggo;

www.Old.fk.ub.ac.id/artikel. Diunduh 12 maret 2014. 